\title{
Discussion on Surgical Multimedia Network Teaching
}

\author{
Shu Jing ${ }^{a}$, and Weihai Jiang ${ }^{b *}$ \\ Affiliated Hospital of Beihua University, Jilin, Jilin,132013, China

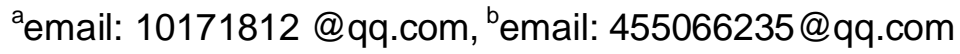 \\ "Corresponding author
}

\begin{abstract}
Keywords: Surgical teaching; Multimedia network; Undergraduate
Abstract. In this study, the advantages, principles and teaching process of surgical multimedia network teaching were summarized, and the teaching effects were statistically analyzed. The success and failure in the reform of the surgical multimedia network teaching were compared, and its effects were analyzed in 200 medical undergraduates. The results showed that the surgical multimedia network teaching could play a good role in the expansion of students' knowledge, the stimulation to students' creative thinking, the development of students' mutual-help character, and establishment of a new teacher-student relationship. Scores of the students taught with the surgical multimedia network teaching method were significantly higher than those of the students taught with the traditional teaching method $(\mathrm{P}<0.05)$, scores of the relevant knowledge outside the syllabus in undergraduates taught with the multimedia internet method were significantly higher than those with the traditional method ( $\mathrm{P}$ $<0.05$ ), suggesting that the surgical multimedia network teaching method should better than the traditional teaching method.
\end{abstract}

\section{Introduction}

Multimedia network is a personal computer system composed of the networking of teacher computer, student computer, servers and consoles, and the most extensive and specific information communication between teachers and students, teachers and teachers, and students and students, can be achieved by virtue of the internet[1-3]. In our hospital, based on multimedia teaching and with the help of campus network, the multimedia network teaching was further developed to expand the students' knowledge, stimulate their creative thinking, develop their mutual character and establish a new relationship between teachers and students.

\section{Characteristics of Surgical Multimedia Network Teaching}

\section{More information and richer contents}

Picture message, animation, surgical video and video of cases or three-dimensional virtual reality could make the teaching contents richer, and can receive the results that could not be achieved by the regular teaching method. The teachers could provide the teaching-related website or teaching content for the students so that students could learn more appropriate interdisciplinary contents and related advanced knowledge, which may widen the students' horizons.

\section{Optimization of classroom teaching to some extent}

Regardless of the traditional teaching methods and multimedia network teaching, syllabus must be 
based on to transfer knowledge to students to the utmost extent. In our teaching practice, the multimedia network might make the electronic courseware teaching in which picture, writing, sound and video were combined possible, which should be unmatched by the traditional teaching. In this way, it is believed that the teachers can get rid of the traditional charts, teaching aids and models, etc., so that the method can both save the time, and make the classroom teaching more vivid.

\section{Enriched contents and manners of after-school review and self-examination}

In general, a good multimedia courseware contains review questions or self-test questions in chapter, and a courseware specifically with mock examination can also be made. The methods described above were used in our practice and the supplement of all the contents enabled the students to further understand the contents of each chapter, and to self-examine themselves. Many contents of surgery can be understood by students only after they are reviewed repeatedly after class. To fully utilize the multimedia network teaching can solve this problem, that is, the students can easily achieve the review result according to their own schedule.

Opening a new surgical experimental teaching approach using computer simulation experiment

Aseptic surgical techniques and basic surgical operations are the main contents in surgical teaching. In the surgical teaching process, the practicality and stringency in the practice were repeatedly emphasized to the students. The establishment of aseptic concept and the understanding of basic surgical operations rely on the repeated operation training, and the classroom training is not enough to realize it. The simulated operation in the simulation laboratory established by computer software technology can make up for the lack of classroom teaching although it can not completely replace the actual operation.

\section{Design and Process of Surgical Multimedia Network Teaching}

\section{Principles of surgical multimedia network teaching}

2.1.1 Student-centered principle: Based on teaching purposes, students are the subject of teaching. In the classroom teaching, the student-centered principle must be followed although the classroom teaching is generally controlled by teachers. There were too much writing and the pictures were changed so fast in the multimedia electronic courseware, so that the students always struggled for the fast-changing images but could not really understand what they should understand or the teachers really wanted to introduce, even could not take notes. Therefore, teachers should fully follow the student-centered principle in the teaching preparation before class and the classroom teaching.

Situation-created principle: Vivid and visual pictures can attract the involuntary attention of students, and problem-based scenes and or to show the value of knowledge learned can stimulate and maintain the voluntary attention of students. In our teaching process, advantages of multimedia were utilized to introduce real clinical cases into the surgical teaching in the form of pictures or video to create a good classroom situation and relaxed classroom atmosphere, which may give the students a realistic feeling.

Information exchange principle: Classroom teaching is a process in which teachers and students exchange information. Through the multimedia network, the teachers could exchange ideas with the students, and the students can discuss some problems with the other students. Due to this reason, the teachers are required to pay full attention to the preparation of information.

\section{Process of surgical multimedia network teaching}

Classroom teaching: In the teaching process, the first was the introduction of the situation and the raise of problems, in order to attract the voluntary and involuntary attention of students. 
After-class teaching: Through multimedia network, students are always able to find their desired courseware on the multimedia network to review the learned contents easily. In our practice, teachers were required to give their own website or E-mail address to facilitate their communication with the students, so that they could receive a good feedback to their teaching from the students and it was convenient for some students who were interested in extracurricular knowledge to cooperate and communicate with teachers in teaching and scientific research.

\section{Results and Analysis of the Teaching}

\section{Theoretical examination results and its analysis instudents taught with two methods}

200 Medical undergraduates were taught in surgery with two different teaching methods. The results of surgical theory examination showed that scores of the students taught with the surgical multimedia network teaching method were significantly higher than those of the students taught with the traditional teaching method $(\mathrm{P}<0.05)$ (Table 1), suggesting that the surgical multimedia network teaching method should better than the traditional teaching method.

Table 1. Comparison on final theoretical scores in students taught with two different methods (mean $\pm \mathrm{s})$

\begin{tabular}{ll}
\hline \multicolumn{1}{c}{ Teaching methods } & Theoretical scores (points) \\
\hline Traditional $(n=100)$ & $76.3 \pm 11.2$ \\
Multimedia internet $\quad(n=100)$ & $81.2 \pm 10.6^{*}$ \\
\hline Compared with those with the traditional method, $\mathrm{P}<0.05$.
\end{tabular}

\section{Analysis on the students' relevant professional knowledge by the end of practice}

By the end of surgical practice, test scores of the relevant knowledge (the knowledge outside the syllabus) were analyzed in 200 medical undergraduates who were taught with the traditional method and the multimedia network method, respectively. As shown in Table 2, scores of the relevant knowledge outside the syllabus in undergraduates taught with the multimedia internet method were significantly higher than those with the traditional method $(\mathrm{P}<0.05)$, indicating that the surgical multimedia internet teaching should be better than the traditional teaching group in the understanding of the knowledge outside the syllabus.

Table 2 Comparison on scores of the knowledge outside the syllabus in students taught with two different methods (mean $\pm \mathrm{s}$ )

\begin{tabular}{ll}
\hline \multicolumn{1}{c}{ Teaching methods } & Test results (points) \\
\hline Traditional $(n=100)$ & $66.8 \pm 9.2$ \\
Multimedia internet $\quad(n=100)$ & $76.6 \pm 9.6 *$ \\
& $*$ : Compared with those with the traditional method, $\mathrm{P}<0.05$.
\end{tabular}

\section{Survey on students' satisfaction with the surgical multimedia network teaching}

The results showed that $98.5 \%$ of the students were interested in the surgery scientific interest; $92.3 \%$ of them considered that the teaching ability of surgical teachers was better than that of the other 
disciplines; $41 \%$ of them knew their teachers' E-mail address; $13 \%$ of them could exchange with some teachers on online; $96 \%$ of them believed that the surgical multimedia network teaching could improve the quality of teaching; $65 \%$ of them thought that that teachers should provide more network information and corresponding website; $43 \%$ of them considered that the related knowledge and the surgical video contained in the surgical multimedia network teaching was not enough; $29 \%$ of them believed that the writing in the surgical multimedia network teaching was too short; $4 \%$ of them took for that the surgical multimedia network teaching was not related to the improvement of teaching quality.

\section{References}

[1]Alanazi A, Elleithy K.Real-Time QoS Routing Protocols in Wireless Multimedia Sensor Networks:

Study and Analysis.Sensors (Basel). 15 ( 2015 ) 22209-33.

[2]Lai YH. A network meta-analysis on the effects of information technology application on preoperative knowledge of patients. Technol Health Care. 23(2015 )1235-37.

[3]Omura M, Levett-Jones T, Stone TE, Maguire J, Lapkin SMeasuring the impact of an interprofessional multimedia learning resource on Japanese nurses and nursing students using the Theory of Planned Behavior Medication Safety Questionnaire.Nurs Health Sci. 2 ( 2015 ) 232-35. 